\title{
KEBEBASAN BERKOMUNIKASI DALAM PERSPEKTIF ISLAM
}

\author{
Rusli \\ Institut Agama Islam Negeri Langsa
}

\begin{abstract}
ABSTRAK
Kebebasan berkomunikasi dalam perspektif Islam adalah suatu sistem komunikasi yang dibangun atas nilai-nilai etika dan prinsip-prinsip yang berlandaskan kepada Al-Quran dan Hadis. Kebebasan berkomunikasi dalam Islam, yaitu bebas menyampaikan pesan-pesan Islami, baik secara lisan, pikiran, dan tulisan kepada khalayak demi kemaslahatan, khususnya bagi umat Islam dan manusia secara umum. Demi tercapainya kebahagiaan di dunia dan akhirat, pesan yang disampaikan kepada komunikan harus benar, jujur, dan dengan cara yang baik, lemah lembut, dan bisa dipertanggung jawabkan baik kepada diri sendiri, masyarakat luas maupun kepada Allah SWT.
\end{abstract}

\section{Kata Kunci : Kebebasan Berkomunikasi, Etika, Prinsip dalam Al-Quran}

\section{A. Pendahuluan}

Kebebasan berkomunikasi merupakan suatu hak yang dimiliki oleh seseorang dalam melakukan penyampaian pesan kepada orang lain. Dengan adanya keterbukaan, kebebasan dan kemerdekaan dalam memberikan informasi kepada masyarakat, maka semakin banyak informasi yang diperoleh oleh masyarakat tersebut. Melihat dunia informasi semakin berkembang untuk menyampaikan pesan kepada masyarakat, kebebasan berkomunikasi dalam perspektif Islam sebagai salah satu sarana untuk menyampaikan informasi yang benar dan bertangung jawab sesuai dengan Al-Quran dan Hadist agar umat Islam mendapatkan informasi yang jujur, benar dan dapat dipertanggung jawabkan.

Komunkasi dalam perspektif Islam suatu sistem komunikasi umat Islam, secara sederhana menunjukkan bahwa komunikasi Islam lebih fokus pada sistemnya dengan latar belakang filosofi (teori) yang berbeda dengan komunikasi perspektif non-Islam. Dengan kata lain sistem komunikasi Islam didasarkan pada Al-Quran dan Hadis. Sudah tentu filisofi atau teori yang menjadi landasan sistem komunikasi Islam mempunyai implikasi-implikasi tertentu terhadap makna proses komunikasi, etika komunikasi dan sebagainya.

W.J. Shepard (dalam Siebert) mengambarkan bahwa adanya pembentukan dua sistem. Pertama, pembentukan sistem secara "spontan dan otomat," dari kesadaran masyarakat akan hak asasinya; serta sanksi sosial dari legalitas institusi. Kedua, ialah sistem kontrol sosial yang terbentuk "pemerintah dalam arti luas" : pemerintah menjadi lembaga pengontrol kegiatan kemasyarakatan disegala demensi sosialnya (Santana, 2005: 221).

Melihat dunia informasi semakin berkembang untuk menyampaikan pesan kepada masyarakat, kebebasan berkomunikasi dalam perspektif Islam sebagai salah satu sarana untuk 
menyampaikan informasi yang benar dan bertangung jawab sesuai dengan Al-Quran dan Hadist agar umat Islam mendapatkan informsi yang jujur, benar dan dapat dipertanggung jawabkan.

Dalam tulisan yang sangat sederhana ini penulis mencoba mennyajikan pengertian kebebasan berkomunikasi, kebebasan berkomunikasi dalam perspektif Islam, Etika-etika dalam komunikasi Islam, dan Prinsip-Prinsip Komunikasi menurut Al-Quran.

\section{B. Pembahasan}

\section{Pengertian Kebebasan Berkomunikasi}

Menurutbahasa bebas ialahlepas sama sekali atau tidak terhalang, terganggu, dan sebagainya sehingga boleh bergerak berbicara, berbuat, dengan leluasa. Kebebasan/kemerdekaan adalah keadaan bebas (Depdiknas, 2008:154-155). Merdeka adalah rasa bebas (tidak merasa terikat oleh sesuatu), tetapi sesuai dengan tuntutan kodrat manusia. Dalam penyataan ini ada dua hal yang kelihatannya saling bertentangan yaitu "rasa bebas" dan "sesuai dengan tuntutan kodrat manusia" yang berarti ada ikatan. Kemerdekaan dalam arti yang sebenarnya memang berlangsung dalam keterikatan. Artinya, bebas berbuat sepanjang tidak bertentangan dengan tututan kodrat manusia. Orang hanya mungkin merasa adanya kebebasan batin apabila ikatan-ikatan yang ada telahmenyatu dengan dirinya, dan menjiwai segenap perbuatannya. Dengan kata lain, ikatan luar (yang membelenggu) telah berubah menjadi ikatan dalam (yang menggerakkan) (Aziz, 2006:7).

Di Indonesia dalam Undang-undang Dasar 1945, pada 28 dinyatakan "Setiap orang berhak untuk berkomunikasi dan memperoleh informasi untuk mengembangkan pribadi dan lingkungan sosialnya, serta berhak untuk mencari, memperoleh, memiliki, menyimpan, mengolah dan menyampaikan infomasi dengan menggunakan segala jenis saluran yang tersedia."

Di Amerika Serikat di bawah Presiden Franklin Delano Rosevelt tahun 1941 menyatakan di muka kongresnya mengenai adanya 4 (empat) kebebasan (the four Freedoms), yang meliputi (Marsudi, 2008:102-103) :

1. Kebebasan untuk berbicara dan menyatakan pendapat (freedom of spech).

2. Kebebasan beragama (freedom ofreligion);

3. Kebebasan dari ketakutan (freedom from fear);

4. Kebebasan dari kekurangan/kemelaratan (freedom from want).

Menurut Hovland, komunikasi merupakan proses di mana seseorang (komunikator) menyampaikan perangsang-perangsang (biasanya lambang-lambang dalam bentuk kata-kata) untuk merubah tingkah laku orang lain. Harold Laswell seorang ahli ilmu politik dari Yale University, mengemukakan bahwa komunikasi adalah peoses pengoperan lambang-lambang, ide gagasan, perasaan, dan pikiran kepada orang lain dengan menjawab pertanyaan-pertanyaan who says what in which chanel towhom with what effect? (siapa, mengatakan apa, dengan saluran/media apa, kepada siapa, dan pengaruhnya bagaimana?)(Drajat, 2008 : 59-60). 
Komunikasi adalah suatu proses penyampaian pesan (ide, gagasan) dari satu pihak kepada pihak lain agar terjadi saling mempengaruhi diantara keduanya. Pada umumnya, komunikasi dilakukan dengan menggunakan kata-kata (lisan) yang dapat dimengerti oleh kedua belah pihak. Apabila tidak ada bahasa verbal yang dapat dimengerti oleh keduanya, komunikasi masih dapat dilakukan dengan menggunakan gerak-gerik badan, menunjukkan sikap tertentu, misalnya tersenyum, menggelengkan kepala, mengangkat bahu. Cara seperti ini disebut komunikasi dengan bahasa nonverbal (Effendy, 2002: 6).

Menurut Devito komunikasi ialah sebagai proses atau tindakan mengirim suatu pesan dari seorang pengirim kepada penerima, melalui satu saluran yang diselingi oleh gangguan. Sementara Gozali merumuskan komunikasi sebagai berlangsungnya aliran informasi, pertukaran gagasan, atau proses saling berbagi makna di antara pengirim dan penerima (Ma'arif, 2010:33).

Teknologi informasi kini telah berkembang dengan sangat pesat. Komunikasi dan informasi berlangsung dengan sangat cepat tanpa batas negara. Proses demokratisasi yang tak dapat dibendung ini juga dipicu oleh perkembangan teknologi informasi. Indonesia sejauh ini telah relatif cukup cepat melakukan antisipasi dengan lahirnya undang-undang yang menjamin adanya kebebasan berkomunikasi dan memperoleh informasi. Undang-undang yang demokratis tentang kemerdekaan memperoleh informasi itu diharapkan segera lahir di Indonesia, melengkapi undangundang yang telah ada sebelumnya. Memang benar, bahwa Pasal 27 ayat (3) U U No. 11 Tahun 2008 tentang Informasi dan Transaksi Elektronik menyebutkan secara lengkap sebagai berikut: "Setiap orang dengan sengaja dan tanpa hak mendistribusikan dan/atau mentransmisikan dan/atau membuat dapat diaksesnya Informasi Elektronik dan/atau Dokumen Elektronik yang memiliki muatan penghinaan dan/atau pencemaran nama baik ." Pasal tersebut memuat unsur "dengan sengaja " dan " tanpa hak". Unsur tersebut menentukan dapat tidaknya seseorang dipidana berdasarkan pasal ini.

Ghani mengatakan, Islam adalah agama yang bersifat missi yang menekankan kepada penganutnya untuk menyampaikan setiap pesan kepada seluruh manusia. Baik kepada muslim maupun yang bukan muslim, untuk menyampaikan segala yang bermanfaat kesejahteraan kepada manusia sejagat (Drajat, 2008:99).

Islam memberikan keyakinan bahwa pembentukan pengetahuan erat kaitannya dengan penciptaan hubungan manusia, alam, dan Tuhan dalam siklus yang tidak terputus. Manusia sebagai subjek ilmu dituntut proaktif memainkan peran khalifahnya di dalam membuat garis-garis hubungan yang akan membentuk dirinya sebagai manusia mu'min muttaqin yang diidamkan. Dalam upaya ini, Islam mengajarkan bahwa setiap anak manusia memiliki kebebasan menentukan dirinya yang akan membawanya pada 'ilmu al-yaqin yang memungkinkan ia bertanggung jawab akan apa yang ia hasilkan (Muhmidayeli, 2011:100). 
Dari beberapa pengertian dikemukakan diatas kebebasan berkomunikasi ialah suatu proses penyampaian pesan dari komunikator kepada komunikan tanpa terikat atau terhalang dengan sesuatu dalam keadaan bebas yang sesuai dengan kodrat manusia. Namun demikian kebebasan berkomunikasi tentu tidak terlepas dari prinsip-prinsip dan etika berkomunikasi yang sesuai dengan kodrat manusia dan tidak menimbulkan fitnah, tentu harus sesuai dengan tuntunan Al-Qur'an dan Hadis.

Kebebasan berkomunikasi menurut John C. Merrill adalah sebagai kondisi yang memungkinkan para pekerja pers memilih menentukan dan mengerjakan tugas mereka sesuai dengan keinginan mereka (Harahap,2000: 109). Teori ini menyatakan tiap orang memiliki hak untuk menyatakan hal-hal yang disukainya : hak untuk kebebasan berpikir, mengungkapkan, serta bergabung dan berserikat. Di sinilah teori ini terkait dengan ideologi demokrasi liberal. "yaitu, keyakinan akan keunggulan individu, akal sehat, kebenaran dan kemajuan, dan kedaulatan rakyat, “ nilai McQuail (Santana, 2005:.224).

Teori ini merupakan suatu teori yang berhubungan dengan pasar bebas seperti yang kita rasakan sekarang ini. Kebebasan pers disamakan dengan kepemilikan media secara privat dan bebas dari campur tangan pihak manapun sebagai sarana dalam berkompetisi ke pasar, menjual dan membeli informasi (gagasan) (Santana, 2005:.225).

Teori tanggung jawab sosial diajukan oleh para politikus dan cerdik pandai Amerika pada pertengahan abad ke-20, setelah melihat bahaya yang ditimbulkan oleh sistem pers liberal. Contohnya ketidak stabilan masyarakat dalam bentuk kebobrokan moral, tingginya kriminalitas, dan intervensi media yang terlalu jauh terhadap pribadi seseorang, dan cenderung media menjadikan masyarakat semata-mata sebagai konsumen belaka untuk mendatangkan finansial melalui penjualan surat kabar kuning, iklan-iklan, yang tidak beretika, serta cendrung memonopoli kepemilikan media di tanggan pemilik modal.

Untuk mengatasi kondisi tersebut, pemerintah Amerika Serikat lalu membentuk suatu badan yang di sebut Komisi Kebebasan Pers Amerika pada tahun 1947 yang dipimpin oleh Robert M. Mutchins dari University of Chicago. Komisi ini dengan disebut Hutchins Commission. Dalam kajian yang dibuatnya, komisi merasa khawatir atas kondisi sosial masyarakat dengan meningkatnya kekuasaan pemilik modal atas media dalam pengendalian informasi. Oleh sebab itu, komisi merekomendasikan agar media memiliki Tanggung Jawab Sosialuntuk menyelamatkan dan mendidik masyarakat demi masa depan Amerika (Canggara,2009:.96-97).

Teori tanggung jawab sosial seperti halnya teori liberal menganut prinsip kebebasan, tetapi antara kedua teori tersebut terdapat perbedaan yang hakiki. Mengenai hal ini, Peterson mengatakan teori liberal dilahirkan dari konsep kemerdekaan yang negatif, yakni kebebasan dari, yang secara lebih tegas lagi, "kebebasan dari pengangkangan eksternal" sedangkan teori tanggung jawab sosial 
berpijak pada konsep kemerdekaan positif, yakni kebebasan untuk, yang menghedaki adanya sarana untuk mencapai tujuan yang diinginkan (Effendy : 1992: 179).

Dasar pemikiran utama dari teori ini ialah bahwa kebebasan dan kewajiban berlangsung secara beriringan dan pers yang menikmati kedudukan dalam pemerintahan yang demokratis berkewajiban dan bertanggung jawab pada masyarakat dalam melaksanakan tugas dan fungsifungsi tertentu yang hakiki.

McQuail merujuk tiga prinsip yang berbeda hendak dikolaborasikan : kebebasan dan pilihan individu, kebebasan media, dan kewajiban media terhadap masyarakat. Untuk itu, teori ini menerima kenetralan dan keseimbangan persterhadap pemerintah dan terhadap soal-soal kontroversial masyarakat. Selain itu, masyarakat diberi hak untuk mengoreksi kesalahan pers. Profesionalisme jurnalisme diminta membawa ukuran "keseimbangan dan kenetralan" dalam pemberitaan (Septiawan: 2005: 225-226).

Jurnalis atau yang terlibat dalam komunikasi massa harus mempunyai tanggung jawab dalam memberitakan sesuatu, apa yang diberitakan oleh media massa harus bisa dipertanggung jawabkan. Jadi jurnalis tidak sekedar menyiarkan informasi tanpa bertanggung jawab akan dampak yang ditimbulkannya. Tanggung jawab ini bisa pada Tuhan, masyarakat, profesi atau dirinya masing-masing (Ardianto, 2007:202).

Teori ini juga mempunyai asumsi utama, bahwa kebebasan mengandung tanggung jawab yang sepadan dan pers yang memiliki tempat terhormat dalam pemerintahan seperti Amerika Serikat, harus bertanggung jawab kepada masyarakat dalam fungsi-fungsi penting komunikasi massa dalam masyarakat modern, asal pers mengetahui tanggung jawabnya dan menjadikan itu sebagai landasan kebijaksanaan operasional mereka. Oleh karena itu teori tanggung jawab sosial merupakan suatu teori yang masih bertahan sampai pada masa sekarang karena dianggap masih sesuai dengan perkembangan masyarakat.

\section{Kebebasan Berkomunikasi dalam Perspektif Islam}

Dalam persperktif Islam, komunikasi merupakan bagian yang tak terpisahkan dalam kehidupan manusia karena segala gerak langkah kita selalu disertai dengan komunikasi. Komunikasi yang dimaksud adalah komunikasi yang islami, yaitu komunikasi yang berakhlak alkarimah atau beretika. Komunikasi yang berakhlak al-karimah berarti komunikasi yang bersumber kepada Al-Qur'an dan hadits. Muis, 2001:720, mengatakan komunikasi islami memiliki perbedaan dengan non-islami. Perbedaan itu lebih pada isi pesan (content) komunikasi yang harus terikat perintah agama, dan dengan sendirinya pula unsur content mengikat unsure komunikator. Artinya, komunikator harus memiliki dan menjunjung tinggi nilai-nilai etika dalam menyampaikan pesan berbicara, berpidato, berkhotbah, berceramah, menyiarkan berita, menulis artikel, mewawancarai, mengkritik, melukis, menyanyi, bermain film, bermain sandiwara di panggung pertunjukan, menari, berolahraga, dan sebagainya (Saefullah, 2007:63-64). 
Komunikasi Islam adalah mengajak menusia kepada jalan dakwah yang lebih menekankan kepada nilai-nilai agama dan sosial budaya, yakni dengan menggunakan prinsip dan kaedah yang terdapat dalam Al-Qurán dan Hadis. Prinsip tersebut bukan hanya sekedar menyampaikan pesan dan terjadinya perubahan perilaku komunikasi, namun terjalinya jaringan interaksi sosial yang harmoni dan berasas normative. Prinsip inilai yag membedakan konsep komunikasi perspektif Islam dengan komunikasi dalam perspektif Barat yang terkesan lebih bersifat culture boud dan banyak terlepas dari unsur normative (Drajat, 2008: 101).

Menurut perspektif Komunikasi Islam, keuntungan paling besar penyampaian informasi pada pihak komunikan (sasaran informasi) bukan pada pihak komunikator. Penyampaian sesuatu informasi pada hakikatnya bertujuan untuk mewujutkan kebahagiaan dan kemaslahatan individu atau masyarakat yang menjadi sasaran komunikasi. Disamping itu kebebasan, berkomunikasi harus dibarengi dengan rasa tangung jawab serta dibatasi oleh nilai-nilai yang dianut oleh masyarakat, bangsa dan negara (Kholil, 2007: 14).

Dalam perspektif komunikasi Islam, proses penyampaian pesan dari komunikator kepada komunikan harus disampaikan secara jujur dan sesuai dengan prinsip-prinsip yang terkandung dalam nilai-nilai Al-Quran dan Sunnah, karena yang demikian dianggap bagian dari ibadah. Maka dalam penerapanya prinsip komunikasi Islam berlangsung antara manusia sekaligus dengan Tuhannya(Drajat, 2008: 101).

Islam menyeru penganutnya supaya menyatakan yang benar. Dalam sebuah hadis yang diriwayatkan oleh Ahmad, nabi Muhammad pernah berkata, "Iman seseorang itu tidak lurus kecuali hatinya lurus, dan hatinya tidak lurus kecuali lidahnya lurus".

Kebebasan berkomunikasi mencakup kebebasan berpikir, kebebasasan berbicara, dan kebebasan mengungkapkan sesuatu. Pengungkapan suatu peristiwa, atau pendapat bisa diekspresikan melalui lisan, pena, atau tindakan (action). Diantara tujuan juranalistik adalah mentranfer, dalam bentuk informasi, tentang perilaku, perasaan dan pikiran manusia. Adanya kebebasan berbicara tersebut terjadi setelah kebebasan berpikir terjamin. Karena itu, takkala membicarakan kebebasan pers dalam Islam, kita perlu menbicarakan tentang kebebasan berpikir dan kebebasan mengeluarkan pendapat (mengekspresikan pendapat dan kritik), menurut perspektif Islam.

Islam menjamin kebebasan berpikir secara konkrit dan nyata. Karena kebebasan ini diatur oleh akhlak dan diawasi setiap saat oleh pantauan Allah SWT. Lebih dari itu, dalam Islam berpikir, melakukan riset dan penelitian di anjurkan dan merupakan suatu ibadah dan metode yang sah untuk mencapai keimanan kepada Allah. Juga mengungkap keagungan kekuasaan dan ciptaanNya (Khoirul, 2009:12). 
Karena Islam menolak setiap klaim yang tidak berdasar pada dalil dan bukti, maka berpikir, tadabbur,meneliti dan mengkaji merupakan kewajiban seluruh umat manusia. Allah berfirman dalam Al-Quran surah An-Naml ayat 64:

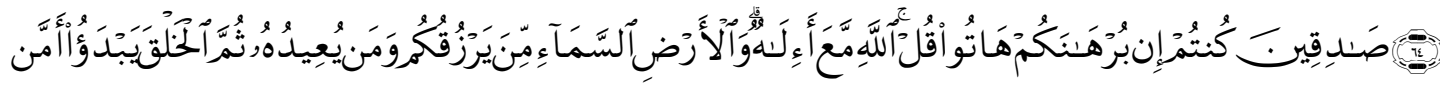

Artinya :

"Atau siapakah yang menciptakan (manusia dari permulaannya), kemudian mengulanginya (lagi), dan siapa (pula) yang memberikan rezki kepadamu dari langit dan bumi? Apakah disamping Allah ada Tuhan (yang lain)?. Katakanlah: "Unjukkanlah bukti kebenaranmu, jika kamu memang orangorang yang benar".(Al-Quran surah An-Naml ayat 64)

Islam juga mewajibkan kepada kaum muslimin untuk mengekpresikan pendapatnya dan melakukan kritik terhadap kesalahan yang terjadi. Ketika hak dirampas, kebenaran diabaikan, dan makin nampak saja penyimpangan di tengah masyaraka, individu muslim tanpa terkecuali, wajib mengambil langkah tegas dan aktif dalam memeranginya. Inilah konsep amar makruf nahi mungkar yang dikenal dalam Islam(Khoirul, 2009:16).

Kebebasan berkomunikasi menurut pandangan Islam bukan bebas tanpa batasan tetapi harus sesuai dengan azas atau norma yang berlaku jangan sampai pers tersebut menyimpang dari azas atau norma tersebut. Sekarang ini kita liat realitanya banyak pers yang menyimpang dari ajaran-ajaran norma yang berlaku misalnya maraknya pers majalah yang bersifat negatif porno aksi, hal tersebut menyimpang dari ajaran agama Islam.

Sementara itu, menurut Ainur Rofiq Sophian terdapat dua pendekatan untuk menjelaskan pengertian media Islam. Pertama, metode pendekatan secara formal. Dalam hal ini media Islam dipahami sebagai media yang diterbitkan oleh umat Islam, menyuarakan aspirasi dan aktivitas umat Islam bertujuan untuk mempertahankan misi dan eksitensi Islam. Kedua, metode pendekatan informal. Yaitu media Islam dinilai dari misi Islam itu sendiri secara global dan holistik, rahmatan lil alamin. Dalam konteks ini sistem Islam lebih banyak diukur dari cita-cita moralitasnya dari semua segi kehidupan. Wujudnya adalah keadilan, kebebasan, persamaan, dan demokrasi (Khoirul, 2009:206).

Dengan demikian Islam menganjurkan penganutnya menyampaikan sesuatu secara jujur, adil, bebas dan memiliki konsepsi aplikasi tentang bagaimana tata hidup yang harmonis dan pesan yang disampaikan mengandung unsur yang mengarahkan manusia kepada kemaslahatan dunia dan akhirat, serta harus sesuai dengan budaya dan agama yang berpedoman pada Al-Quran dan Hadist.

\section{Etika Komunikasi Islam}

a. Pengertian Etika Komunikasi Islam

Secara etimologis etika dapat diartikan sebagai: 1) ilmu tentang apa yang baik dan apa yang buruk dan tentang hak dan kewajiban moral; 2) kumpulan asa/nilai yang berkenaan dengan 
akhlak; 3) nilai mengenai benar dan salah yang dianut suatu golongan atau masyarakat (Kholil, 2007:25).Sobur menyebutkan etika adalah filsafat moral yang berkenaan dengan kewajibankewajiban tentang baik buruknya dan benar salah (Ardianto, 2007:196).

Etika komunikasi merupakan bagian dari upaya untuk menjamin otonomi demokrasi. Etika komunikasi tidak hanya berhenti pada masalah perilaku aktor komunikasi (wartawan, editor, agen iklan, dan pengelola rumah produksi). Etika komunikasi berhubungan juga dengan praktek institusi, hukum, komunitas, struktur sosial, politik dan ekonomi. Lebih dari itu, etika komunikasi selalu dihadapkan dengan berbagai masalah, yaitu antara kebebasan berekspresi dan tanggung jawab terhadap pelayanan publik. Etika komunikasi memilik tiga dimensi yang terkait satu dengan yang lain, yaitu aksi komunikasi, sasaran dan tujuan.

Etika merupakan cermin dari pandangan masyarakat dari yang baik dan yang buruk, sekaligus menjadi salah satu indikator untuk membedakan antara sikap dan perilaku diterima atau ditolak dengan tujuan untuk mencapai kebaikan dalam hidup bersama. Etika juga dijadikan sebagai standar moral yang mengatur perilaku manusia yang merupakan dialektika antara kebebasan dan tanggung jawab, antara tujuan yang baik dan yang buruk.

Dalam perspektif umum ini, etika komunikasi dibagi menjadi beberapa bahasan yaitu, etika komunikasi antarpersona, etika komunikasi antarbudaya, etika komunikasi massa. Lalu terdapat juga etika komunikasi dalam perspektif islam.

Syukur Kholil mengatakan etika komunikasi Islam dapat diartikan sebagai nilai-nilai yang baik dan yang buruk, yang pantas dan yang tidak pantas, yang berguna dan yang tidak berguna, dan yang harus dilakukan dengan yang tidak boleh dilakukan ketika melakukan aktivitas komunikasi. Nilai-nilai etika komunikasi Islami itu bersumber dari pokok ajaran Islam, yaitu Al-Qur'an dan Hadis(Kholil, 2007:26).

\section{b. Nilai-nilai Etika Komunikasi Islam}

Nilai-nilai etika komunikasi Islam pada sangat luas sekali. Namun namun secara umum nilai-nilai komunikasi Islam itu ialah : 1) bersikap jujur, 2) menjaga akurasi pesan-pesan komunikasi, 3) bersifat bebebas bertanggung jawab, dan 4) dapat memberikan kritik membangun.

Dalam Al-Qur'an surah an-Nuur ayat 19 Allah berfirman :

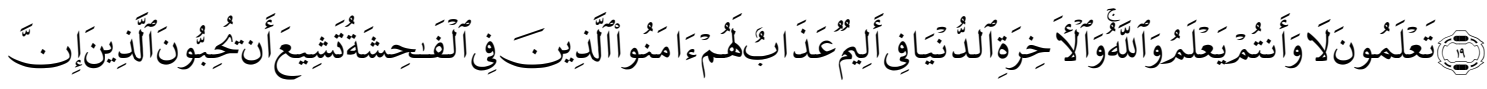

Artinya : Sesungguhnya orang-orang yang ingin agar (berita) perbuatan yang Amat keji itu tersiar di kalangan orang-orang yang beriman, bagi mereka azab yang pedih di dunia dan di akhirat. dan Allah mengetahui, sedang, kamu tidak mengetahui. (Al-Quran surah an-Nuur ayat 19). 
Dari ayat di atas dapat dipahami bahwa prinsip komunikasi Islam dengan tegas Allah melarang menyebarkan berita-berita yang keji ditengah-tengah umat, karena dapat menimbulkan berbagai kekacauan di tengah-tengah masyarakat. Barang siapa yang menyebarkan informasi yang tidak benar maka azab Allah sangat pedih baik di dunia maupun di akhirat.

1) Bersifat jujur

Dalam Al-Qur'an, jujur identik dengan amanah, tidak menyampaikan hal-hal yang tidak diketahui, adil atau tidak memihak, tidak bertentangan antara ucapan dan perbuatan, serta mempertimbangkan kewajaran dan kelayakan suatu informasi untuk disiarkan.

Secara sederhana amanah dapat diartikan sebagai kepercayaan yang lebih berkonotasi kepada kepercayaan kepada Tuhan. Komunikator dituntut untuk menjaga amanah. Tidak menyampaikan hal-hal yang tidak boleh diinformasikan. Kemudian sifat jujur dalam Al-Qur'an dikenal dengan istilah siddiqyang secara harfiyah artinya benar. Dalam konteks komunikasi Islam, berbohong merupakan sifat tercela sebab dapat menyesatkan individu dan masyarakat(Kholil, 2007:27).

Sehubungan dengan etika kejujuran dalam komunikasi, ayat-ayat Alquran memberi banyak landasan. Hal ini diungkapkan dengan adanya larangan berdusta dalam surah an-Nahl ayat 116 Allah berfirman:

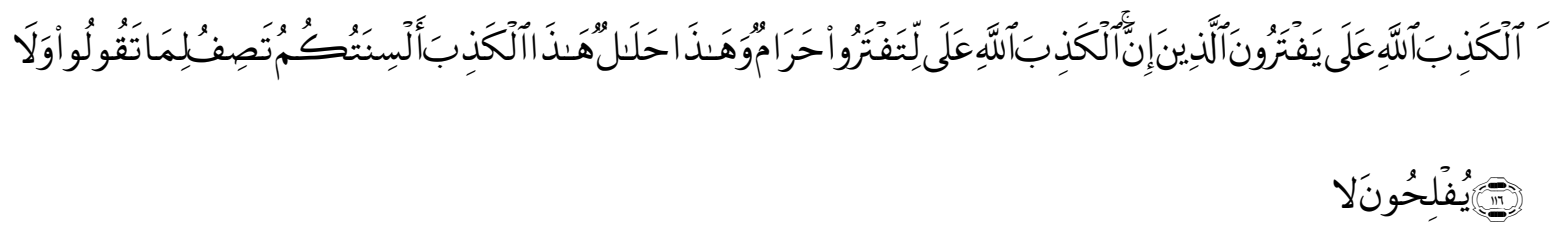

Artinya : dan janganlah kamu mengatakan terhadap apa yang disebut-sebut oleh lidahmu secara Dusta "Ini halal dan ini haram", untuk mengada-adakan kebohongan terhadap Allah. Sesungguhnya orang-orang yang mengada-adakan kebohongan terhadap Allah Tiadalah beruntung.(Al-Quran surah an- an-Nahl ayat 116).

Nabi Muhammad SAW bersabda dalam sebuah hadis, beliau mengatakan "Jika kamu berbicara (menyampaikan ucapan) tentang sesuatu perkara kepada suatu kaum padalah perkara itu tidak terjangkau (tidak dipahami) oleh akal pikiran mereka, niscaya akan membawa fitnah di kalangan mereka. (HR. Muslim) (Almath, 1991:162).

Oleh karena itu seorang komunikator tidak boleh menyampaikan hal-hal yang tidak diketahui secara pasti kebenaranya, samar-samar, atau kabar-kabar angin yang tidak jelas sumbernya. Karena informasi tersebut dapat menyesatkan orang lain, dan dapat menimbulkan fitnah serta menghukum orang yang tidak bersalah.

Dalam kegiatan komunikasi Islam, seorang wajib mempertimbangkan wajar tidaknya suatu informasi untuk disampaikan. Informasi yang dapat menggangu ketentraman dan keselamatan 
seseorang, kelompok, masyarakat, bangsa, negara, tidak boleh dipublikasikan. Demikian juga yang dapat menyinggung perasaan umat beragama, ras, suku dan golongan(Kholil, 2007:27) Seperti Firman Allah SWT dalam Al-Qur'an surat al-An'am ayat 108.
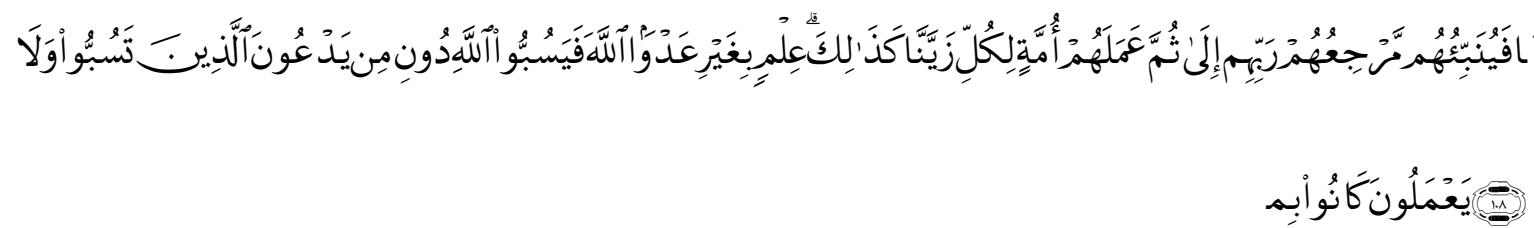

Artinya : dan janganlah kamu memaki sembahan-sembahan yang mereka sembah selain Allah, karena mereka nanti akan memaki Allah dengan melampaui batas tanpa pengetahuan. Demikianlah Kami jadikan Setiap umat menganggap baik pekerjaan mereka. kemudian kepada Tuhan merekalah kembali mereka, lalu Dia memberitakan kepada mereka apa yang dahulu mereka kerjakan.(Al-Qur'an surat al-An'am ayat 108).

2) Keakuratan Informasi

Informasi yang disampaikan haruslah yang benar-benar akurat, setelah lebih dahulu diteliti secara cermat dan seksama. Setiap komunikan harus senantiasa bersikap teliti dan hati-hati dalam menerima informasi, sehingga tidak merugikan diri sendiri dan orang lain. Al-Quran misalnya memerintahkan untuk melakukan koreksi atas informasi yang diterima. Allah SWT berfirman dalam surah al-Hujurat ayat 6 dikatakan:

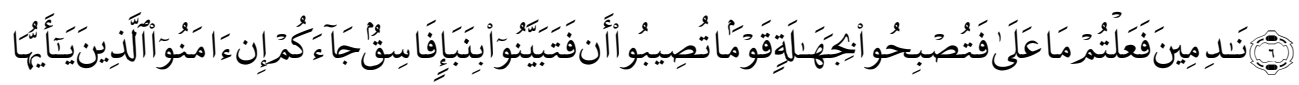

Artinya : Hai orang-orang yang beriman, jika datang kepadamu orang Fasik membawa suatu berita, Maka periksalah dengan teliti agar kamu tidak menimpakan suatu musibah kepada suatu kaum tanpa mengetahui keadaannya yang menyebabkan kamu menyesal atas perbuatanmu itu.(Q.S. Surat Al-Hujurat Ayat 6).

Dari ayat di atas dapat dipahami bahwa adanya pihak-pihak yang menyebarkan informasi yang tidak benar atau informasi yang buruk. Kalau informasi yang disebarkan tidak chek and rechek secara teliti boleh jadi akan ditimpakan malapetaka dari informasi tersebut. Oleh sebab itu setiap informasi yang disampaikan oleh seseorang haruslah dicermati terlebih dahulu sehingga tidak terjadi musibah didalam masyarakat.

Al-Quran mengisyaratkan adanya orang-orang yang ingin dan berusaha agar suatu infomasi yang buruk itu tersebar ditengah-tengah masyarakat. Karena itu seseorang harus terlibat dalam kegiatan komunikasi, harus teliti terhadap kebenaran sesuatu informasi yang diterimanya sebelum disampaikan kepada orang lain. Seperti Firman Allah dalah Al-Quran surat An-Nur ayat 19. 


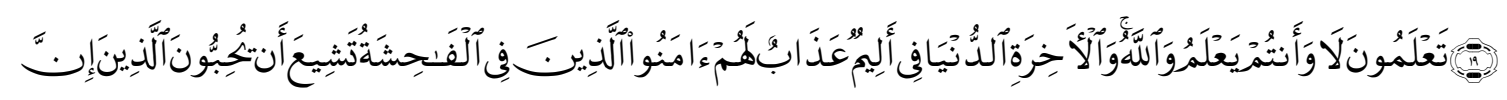

Artinya : Sesungguhnya orang-orang yang ingin agar (berita) perbuatan yang Amat keji itu tersiar di kalangan orang-orang yang beriman, bagi mereka azab yang pedih di dunia dan di akhirat. dan Allah mengetahui, sedang, kamu tidak mengetahui. (Q.S. An-Nur ayat 19)

3) Bebas bertanggung jawab

Kebebasan berkomunikasi dalam Islam, dalam hal ini komunikator mempunyai kebebasan dalam menerima dan menyampaikan informasi, baik secara lisan, tulisan ataupun isyarat. Komunikator juga tidak dapat memaksakan kehendaknya agar pesan-pesan yang disampaikan dapat diterima oleh orang lain. Walaupun pesan yang disampaikan itu mengandung nilai-nilai kebenaran sekalipun, termasuk nilai-nilai agama sekalipun(Kholil, 2007:29).

Kebebasan yang diberikan untuk menerima dan menyampaikan informasi tersebut, harus dibarengi dengan rasa tanggung jawab. Dalam hal ini informasi yang disampaikan itu haruslah benar, dan cara penyampaiannya juga dengan cara yang benar, agar dapat mewujudkan kemaslahatan bagi kehidupan manusia.

Menyangkut masalah tanggungjawab dalam Al-Quran surah al-Isra' ayat 36 dijelaskan bahwa: “

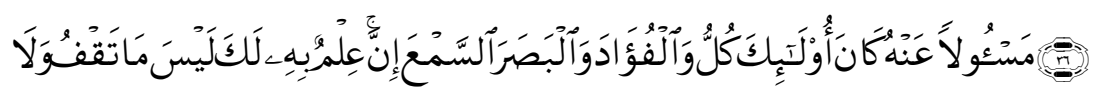

Artinya : dan janganlah kaтu mengikuti apa yang kamu tidak mempunyai pengetahuan tentangnya. Sesungguhnya pendengaran, penglihatan dan hati, semuanya itu akan diminta pertanggungan jawabnya.. (Q.S. al-Isra' ayat 36).

Dari penjelasan ayat diatas seorang komunikator harus mempunyai pengetahuan terhadap informasi yang ingin disampaikan kepada orang lain.Seorang komunikator harus bertanggung jawab atas apa yang disampaikan kepada komunikan baik di dunia dan diakhiran kelak.dimana berita itu diperoleh semuanya harus bisa dipertangung jawabkan baik kepada sesama manusia maupun kepada Tuhan.

4) Kritik membangun

Dalam komunikasi Islam kritik yang membangun sangat diperlukan, untuk dapat menjadi bahan perbaikan di masa yang akan datang, dan dapat terhindar dari kesalahan di masa lalu. AlQuran juga menyediakan ruangan yang cukup banyak dalam menjelaskan etika kritik konstruktif dalam berkomunikasi. Salah satunya tercantum dalam surah Ali Imran ayat 104 Allah berfirman:

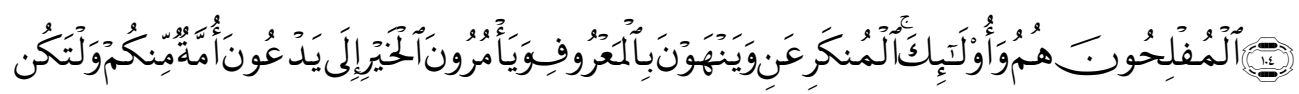


Artinya : dan hendaklah ada di antara kamu segolongan umat yang menyeru kepada kebajikan, menyuruh kepada yang ma'ruf dan mencegah dari yang munkar; merekalah orang-orang yang beruntung.(Q.S. Ali Imran ayat 104).

Ma'ruf ialah segala perbuatan yang mendekatkan kita kepada Allah; sedangkan Munkar ialah segala perbuatan yang menjauhkan kita dari pada-Nya.Di ayat yang lain Allah berfirman dalam surat A-Sar ayat 1-3.

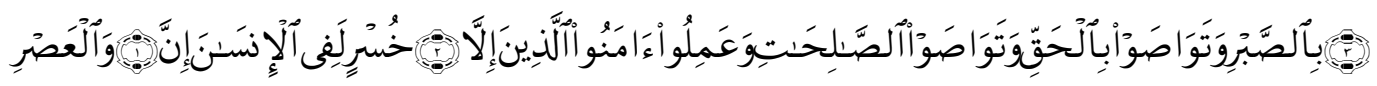

Artinya : demi masa, Sesungguhnya manusia itu benar-benar dalam kerugian, kecuali orang-orang yang beriman dan mengerjakan amal saleh dan nasehat menasehati supaya mentaati kebenaran dan nasehat menasehati supaya menetapi kesabaran.(Q.S. Al 'Ashr, ayat 1-3).

Di samping kegiatan-kegiatan komunikasi yang disuruh untuk dilakukan komunikator, juga ada tindakan-tindakan komunikasi yang harus dihindari oleh kamunikator dalam komunikasi Islam, yaitu mengutuk orang lain, memandang remeh orang lain, membocorkan rahasia orang lain, mengupat, memuji berlebiha, memberi salam kepada orang kafir, bertengkar, mengucapkan katakata kotor, berbisik-bisik antar dua orang, dan berkata kafir kepada seorang muslim(Kholil, 2007:30)

\section{Prinsip-Prinsip Komunikasi menurut Al-Qur’an}

Kaidah, prinsip, atau etika komunikasi Islam ini merupakan panduan bagi kaum muslim dalam melakukan komunikasi, baik dalam komunikasi intrapersonal, interpersonal dalam pergaulan sehari hari, berdakwah secara lisan dan tulisan, maupun dalam aktivitas lain. Dari berbagai literatur tentang komunikasi Islam kita dapat menemukan setidaknya enam jenis gaya bicara atau pembicaraan (qaulan) yang dikategorikan sebagai kaidah, prinsip, atau etika komunikasi Islam. Allah SWT menciptakan manusia, mengajarkan Al-bayan (pandai berbicara). Asy-Syaukani dalam tafsir Fath-Al-Qadir mengartikan al-Bayan sebagai kemampuan berkomunikasi. Untuk mengetahui bagaimana orang-orang seharusnya berkomunikasi, kita harus melacak kunci (key concept) yang dipergunakan Al-Quran untuk komunikasi. Selain al-Bayan, kata kunci untuk berkomunikasi yang banyak disebutkan dalam Al-Quran adalah al-Qaul. Dengan memperhatikan kata qaul dalam konteks perintah (amr), terdapat enam prinsip komunikasi yaitu : qaulan sadidan, qaulan balighan, qaulan ma'rufan,qaulan kariman, dan qaulan maysuran(Saefullah, 2007:67-68).

\section{a. Qaulan Sadidan}

Qaulan Sadidaartinya pembicaraan yang benar, jujur, lurus, tidak berbohong, dan tidak berbelit-belit. Prinsip komunikasi yang pertama menurut Al-Quran adalah berkata benar. Ada beberapa makna dari pengertian benar sesuai dengan kriteria kebenaran Al-Quran. Salah satunya adalah sesuai dengan kriteria kebenaran. Buat orang lain, ucapan yang benar, tentu ucapan yang 
sesuai dengan Al-Quran, sunnah, dan ilmu. Al-Quran mengisyarakan bahwa perkataan yang benar tidaknya dianjurkan untuk diri sendiri, akan tetapi harus diwarisi kepada siapapun yang ada didunia ini, termasuk pada keturunan kita, sehingga perkataan yang benar itu selalu terpelihara sampai kapanpun, seperti firman Allah surat An-Nisaa ayat 9. yang berbunyi :

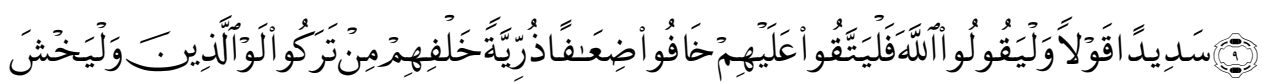

Artinya : dan hendaklah takut kepada Allah orang-orang yang seandainya meninggalkan dibelakang mereka anak-anak yang lemah, yang mereka khawatir terhadap (kesejahteraan) mereka. oleh sebab itu hendaklah mereka bertakwa kepada Allah dan hendaklah mereka mengucapkan Perkataan yang benar.(Q.S. An-Nisaa, ayat 9).

Al-Quran menyatakan bahwa berbicara yang benar dan menyampaikan pesan yang benar adalah persyaratan untuk kebesaran (kebaikan, kemaslahatan) amal. Apabila kita ingin memperbaiki masyarakat kita, kita harus menyampaikan pesan-pesan yang benar. Masyarakat menjadi rusak apabila pesan yang disampikan oleh komunikator tidak benar dan menyembunyikan kebenaran karena takut pada penguasa. Penguasa yang menyembunyikan kebenaran, atau berbohong, menipu, menurut Al-Quran tidak akan bertahan lama dan mengalami keruntuhan.

Al-Quran mengajarkan bahwa salah satu cara memperbaiki masyarakat ialah memperbaiki bahasa yang kita pergunakan untuk mengungkapkan realitas, bukan untuk menyebunyikannya, untuk lebih jelas dapat kita lakukan dengan cara, yaitu tidak berbohong, dan kita harus mengetahui apa dampak dari berbohong itu.

1) Tidak Berbohong

Arti kata dari qaulan sadidan adalah tidak berbohong. Nabi Muhammad SAW bersabda, "hendaklah kamu selalu benar. Sesungguhnya kebenaran membawa kepada kebajikan dan kebajikan membawa ke surga. Selama seorang benar dan selalu memilih kebenaran dia tercatat di sisi Allah seorang yang benar (jujur). Hatihatilah terhadap dusta. Sesungguhnya dusta membawa kepada kejahatan dan kejahatan membawa kepada neraka. Selama seorang dusta dan selalu memilih dusta dia tercatat di sisi Allah sebagai seorang pendusta (pembohong)". (HR. AlBukhari)(Almath, 1991:277).

Al-Quran menyuruh kita selalu berkata benar, supaya kita tidak meninggalkan keturunan yang lemah. Anak-anak dilatih berkata jujur. Kejujuran melahirkan kekuatan. Kebohongan melahirkan kelemahan. Biasa berkata benar mencerminkan keberanian. Bohong sering lahir karena rendah diri, pengecut, dan penakut. Dalam komunikasi Islam seorang komunikator harus menginformasikan atau menyampaikan kebenaran, faktual, hal yang benar saja, jujur, tidak berbohong, juga tidak merekayasa atau memanipulasi fakta. 
Seorang muslim harus berkata benar, jujur tidak berdusta. Sebab sekali kita berkata dusta, selanjutnya kita akan berdusta untuk menutupi dusta kita yang pertama, begitu seterusnya, sehingga bibir kita pun selalu berbohong tanpa merasa berdosa. Siapapun tak ingin dibohongi, seorang istri akan sangat sakit hatinya bila ketahuan suaminya berbohong, begitu juga sebaliknya. Rakyat pun akan murka bila dibohongi pemimpinnya. Juga tidak kalah penting dalam menyampaikan kebenaran, adalah keberanian untuk bicara tegas, jangan ragu dan takut, apalagi jelas dasar hukumnya yaitu Al Quran dan hadits.

2) Bahaya Bohong

Bohong merupakan perbuatan yang tercela dalam pandangan Islam, sebab jika suatu berita atau informasi yang disampaikan oleh komunikator dusta atau bohong, akan berdampak kepada kemaslahatan bagi kehidupan manusia baik di dunia maupun di akhirat telak.

Bahayanya berbohong dapat merusak tatanan kehidupan masyarakat secara luas. Apa lagi kebohongan itu dilakukan dengan cerita bohong atau berdusta yang bermaksud untuk menertawakan orang lain. Seperti Sabda Nabi Muhammad SAW "Celaka bagi orang yang bercerita kepada satu kaum tentang kisah bohong dengan maksud agar mereka tertawa. Celakalah dia...celaka dia. (H.R. Abu daud dan Ahmad) ((Almath, 1991:278).

\section{b. Qaulan Baligha}

Qulan Balighaadalah perkataan yang memberi bekas pada jiwa komunikan. Kata beligh berarti fasih, jelas maknanya, terang, tepat mengungkapkan apa yang dikehendaki. Oleh karena itu, prinsip qaulan balighan dapat diterjemahkan sebagai prinsip komunikasi persuasif. Seperti firman Allah SWT dalam Al-Quran surat An.Nisaa ayat 63.

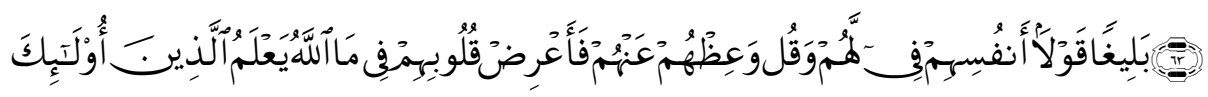

Artinya: mereka itu adalah orang-orang yang Allah mengetahui apa yang di dalam hati mereka. karena itu berpalinglah kamu dari mereka, dan berilah mereka pelajaran, dan Katakanlah kepada mereka Perkataan yang berbekas pada jiwa mereka. (Q.S. An-Nisaa ayat 63).

Penjelasan dalam Al-Quran dapat mengambarkan bahwa kita memperoleh isyarat bahwa informasi atau pesan yang disampaikan itu menduduki posisi sentralnya. Perspektif Al-Quran menunjukkan betapa suatu pesan perlu dirangkai sedemikian rupa sehingga dapat menyentuh hati pendengarnya. Jalaluddin Rahmat memberikan pengertian qaulan baligha menjadi dua,qaulan balighaterjadi bila da'i (komunikator) menyesuaian pembicaraannya dengan sifat-sifat khalayak yang dihadapinya sesuai dengan frame of reference and field of experience. Kedua,qaulan baligha terjadi bila komunikator menyentuh khalayaknya pada hati dan otaknya sekaligus.

Jika dicermati pengertian qaulan baligha yang diungkapkan oleh jalaluddin rahmat tersebut maka dapat disimpulkan bahwa kata Qaulan Baligha artinya menggunakan kata-kata yang 
efektif, tepat sasaran, komunikatif, mudah dimengerti, langsung ke pokok masalah (straight to the point), dan tidak berbelit-belit atau bertele-tele.

Rasulullah sendiri memberi contoh dengan khotbah-khotbahnya, yang umumnya pendek, namun kata-katanya padat makna. Nabi menyebutnya jawami' al-qalam. Beliau berbicara dengan wajah yang serius dan kata-kata yang sedapat mungkin menyentuh hati para pendengarnya. Irbadh bin Sariyah, salah seorang sahabatnya bercerita, "Suatu hari Nabi menyampaikan nasihat kepada kami. Seorang diantara kami bertanya, Ya Rasulullah, seakan-akan baru kami dengar khotbah perpisahan, tambahkanlah kami wasiat". Tidak jarang di sela-sela khotbahnya nabi berhenti untuk bertanya kepada yang hadir atau memberi kesempatan kepada yang hadir untuk bertanya. Dengan segala otoritasnya, Nabi adalah orang yang senang membuka dialog(Saefullah,2007:72).

Qulan Baligha terjadi bila komunikator menyesuaikan pembicaraanya dengan sifat-sifat komunikan. Dalam istilah Al-Quran, ia berbicara fi anfusihim (tentang diri mereka). Dalam istilah sunah, "Berkomunikasilah kamu sesuai dengan kadar akal mereka". Seperti Firman Allah dalam Al-Quran surat Ibrahim, ayat 4) yang berbunyi.

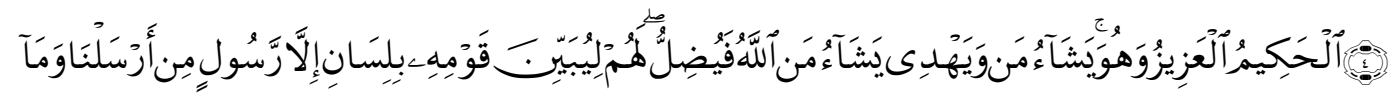

Artinya : Kami tidak mengutus seorang rasulpun, melainkan dengan bahasa kaumnya, supaya ia dapat memberi penjelasan dengan terang kepada mereka. Maka Allah menyesatkan, siapa yang Dia kehendaki, dan memberi petunjuk kepada siapa yang Dia kehendaki. dan Dia-lah Tuhan yang Maha Kuasa lagi Maha Bijaksana. (Q.S. Ibrahim, ayat 4).

\section{3) Qaulan Ma'rufan}

Qaulan Ma'rufanyang berarti perkataan yang baik.Secara sistematik, kata ma'rufberarti kebaikan yang diketahui, dalam arti kebaikan yang bersifat operasional, lokal, dan bahkan sesaat. Menusia selalu menciptakan maknanya sendiri dalam kehidupan yang selalu berubah ini (Ma'arif, 2010:76-77).Di samping perkataan yang bisa memberi bekas pada komunikan, seorang komunikator juga harus menggunakan perkataan yang baik pula, seperti firman Allah dalam AlQuran surat Al-Israa' ayat 53.

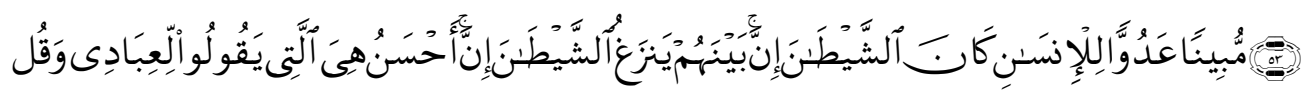

Artinya : dan Katakanlah kepada hamha-hamba-Ku: "Hendaklah mereka mengucapkan Perkataan yang lebih baik (benar). Sesungguhnya syaitan itu menimbulkan perselisihan di antara mereka. Sesungguhnya syaitan itu adalah musuh yang nyata bagi manusia. (Q.S. Al-Israa' ayat 53).

Dalam Surat Al-Bakharah ayat 263, Allah juga berfirman : 


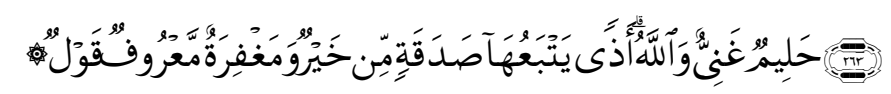

Artinya : Perkataan yang baik dan pemberian maaf, lebih baik dari sedekah yang diiringi dengan sesuatu yang menyakitkan (perasaan si penerima). Allah Maha Kaya lagi Maha Penyantun.(Q.S. Al-Baqarah, ayat 263).

Dalam ayat ini Allah menjelaskan ketika berbicara tentang kewajiban orang-orang kaya atau kuat terhadap orang-orang miskin atau lemah.qaulan ma'rufan berarti pembicaraan yang bermamfaat memberikan pengetahuan, mencerahkan pemikiran, menunjukan pemecahan terhadap kesulitan kepada orang lemah, jika kita tidak dapat membantu secara material,kita harus dapat membantu psikologi. Pemberian maaf lebih baik dari pada memberikan sedekah, tetapi menyakiti sipenerimanya.

\section{4) Qaulan Karima}

Qaulan Karima berarti perkataan yang mulia. Suatu perkataan disebut mulia apabila tidak menjatuhkan mertabat orang tua. Perkataan mulia bila sikap dan perilaku subjek yang menyatakannya betul-betul memuliakan kedua orang tua karena perkataan merupakan ekspresi dari kesejatian diri. Seorang anak hendaknya berlaku lembut dan tidak berlaku kasar kepada kedua orang tuanya, baik ucapan, sikap, maupun perbuatan. Kemuliaan yang kita peroleh sesungguhnya merupakan jerih payah orang tua kita(Ma'arif, 2010:77).Allah berfirman dalam surat Al-Israa ayat 23.

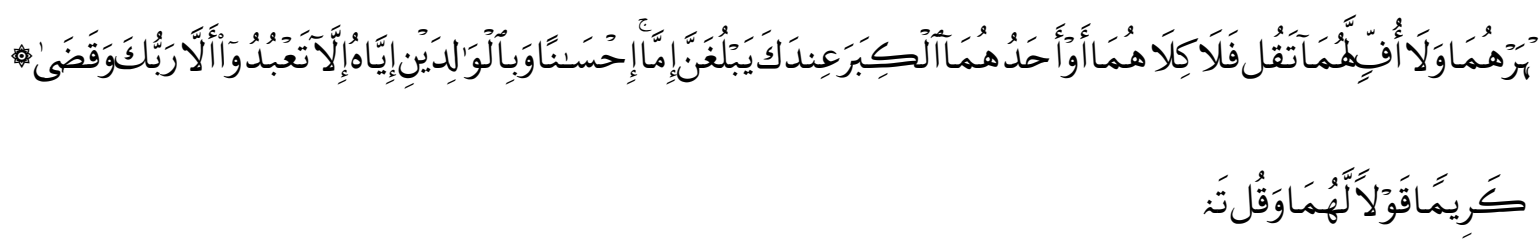

Artinya : dan Tuhanmu telah memerintahkan supaya kamu jangan menyembah selain Dia dan hendaklah kamu berbuat baik pada ibu bapakmu dengan sebaik-baiknya. jika salah seorang di antara keduanya atau Kedua-duanya sampai berumur lanjut dalam pemeliharaanmu, Maka sekalikali janganlah kaтu mengatakan kepada keduanya Perkataan "ah" dan janganlah kamu membentak mereka dan ucapkanlah kepada mereka Perkataan yang mulia (Q.S. Al-Israa ayat 23).

Dalam ayat ini Allah SWT menjelaskan kepada kita yang bahwa hendaklah kita berbuat baik kepada kedua orang tua. Mengucapkan kata Ah kepada orang tua tidak dlbolehkan oleh agama apalagi mengucapkan kata-kata atau memperlakukan mereka dengan lebih kasar daripada itu.

Nabi Muhammad SAW bersabda "Seorang sahabat bertanya, "Yarasulullah, siapa yang paling berhak memperoleh pelayanan dan persahabatanku?" Nabi Saw menjawab, “ibuти...ibuти...ibumu, kemudian ayahmu dan kemudian yang lebih dekat kepadamu dan yang lebih dekat kepadamu.’(Mutaffak 'Alaih). 
Perkataan yang mulia harus dibarengai dengan perkataan yang baik, dari penjelasan Allah SWT, dan sabda Rasulullah Saw mengisyaratkan kepada kita bahwa perkataan yang sangat mulia harus dibarengi dengan perkataan yang lembut, dan diikuti dengan perilaku kita baik kepada kedua orang tua kita maupun kepada orang lain.

\section{5) Qaulan Layyinan}

Qaulan Layyinan menurut Al-Maraghi, dalam Tafsirnya Al-Maraghi, berarti pembicaraan yang lemah lembut agar lebih dapat menyentuh hati dan menariknya untuk menerima dakwah. Dengan perkataan yang lemah lembut, hati orang-orang yang durhaka akan menjadi halus, dan kekuatan orang-orang yang sombong akan hancur. Menurut Ibnu Kasir, yang dimaksud dengan layyinan ialah kata-kata sindiran (bukan dengan kata-kata terus terang). Hal yang sama telah diriwayatkan Sufyan As-Sauri bahwa sebutlah dia dengan julukan Abu Murrah. Pada garis besarnya, pendapat mereka menyimpulkan bahwa Musa dan Harun diperintahkan oleh Allah SWT agar memakai kata-kata yang lemah lembut, sopan-santun, dan belas kasihan dalam dakwahnya kepada Firaun, agar kesannya lebih mendalam dan lebih menggugah perasaan, serta dapat membawa hasil yang positif (Saefullah,2007:92-93).Allah berfirman dalam Al-Quran surat Thaahaa ayat 44 yang berbunyi :

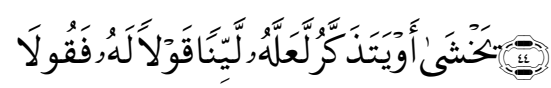

Artinya : Maka berbicaralah kamu berdua kepadanya dengan kata-kata yang lemah lembut, Mudah-mudahan ia ingat atau takut".(Q.S. Thaahaa ayat 44).

Dari ayat tersebut menjelaskan bahwa qaulan layyinan berarti pembicaraan yang lemahlembut, dengan suara yang enak didengar, dan penuh keramahan, sehingga dapat menyentuh hati maksudnya tidak mengeraskan suara, seperti membentak, meninggikan suara. Siapapun tidak suka bila berbicara dengan orang-orang yang kasar. Rasullulah selalu bertuturkata dengan lemah lembut, hingga setiap kata yang beliau ucapkan sangat menyentuh hati siapapun yang mendengarnya.

\section{6) Qaulan Maysuran}

Secara etimologis, kata maysuran berasal dari kata yasarayang artinya mudah atau gampang. Ketika kata maysura digabungkan dengan qaulan menjadi Qaulan Maysuran yang artinya berkata dengan mudah atau gampang. Berkata dengan mudah maksudnya adalah kata-kata yang digunakan mudah dicerna, dimengerti, dan dipahami oleh komunikan. Kata yang mudah dipahami ialah kata-kata yang mengandung makna denotatif, yaitu kata-kata yang mengandung arti sebagaimana tercantum dalam kamus (dictionary meaning), bukan kata-kata konotatif, yaitu katakata yang mengandung makna emosional atau mengandung penilaian tertentu (Saefullah,2007:98).

Sebagaimana Allah SWT berfirman dalam Al-Quran surat Al-Israa' ayat 28 yang berbunyi 


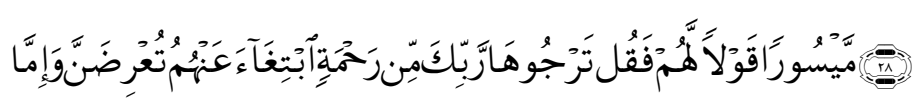

Artinya : dan jika kamu berpaling dari mereka untuk memperoleh rahmat dari Tuhanmu yang kamu harapkan, Maka Katakanlah kepada mereka Ucapan yang pantas.(Q.S. Al-Israa' ayat 28).

Ucapan yang pantas Maksudnya: apabila kamu tidak dapat melaksanakan perintah Allah seperti yang tersebut dalam ayat 26, Maka Katakanlah kepada mereka Perkataan yang baik agar mereka tidak kecewa lantaran mereka belum mendapat bantuan dari kamu. dalam pada itu kamu berusaha untuk mendapat rezki (rahmat) dari Tuhanmu, sehingga kamu dapat memberikan kepada mereka hak-hak mereka.

Ayat tersebut ditujukan kapada Nabi Muhammad Saw dan umatnya untuk selalu berkata qaulan maysuran(kata-kata yang mudah dan baik), walaupu mereka (orang-orang musyrik nonIslam) menghina dan mencomooh kita (umat Islam). Begitu pula ketika orang dekat, orang miskin dan musafir meminta bantuan kepada kita, sedangkan kita tidak memiliki apa-apa, maka katakanlah kepada mereka perkataan yang lunak dan baik (Qaulan Maysuran).

\section{Penutup}

Kebebasan berkomunikasi dalam perspektif Islam adalah suatu proses penyampaian pesan dari komunikator kepada komunikan secara benar, jujur dan sesuai dengan nilai-nilai etika dan prinsip-prinsip yang terkandung dalam Al-Quran dan Hadits. Kebebasan komunikasi dalam Islam yaitu bebas menyampaikan pikiran atau gagasan, ktitikan konstruktif baik berupa lisan maupun tulisan kepada orang lain, yang bertujuan untuk kemaslahatan umat baik di dunia maupun di akhir telak dan bisa dipertangung jawabkan kepada sesama manusia maupun kepada Allah SWT.

Dalam proses penyampaian pesan, seorang komunikator harus mempergunakan nila-nilai etika dan prinsip-prinsip yang berlandaskan pada Al-Quran dan Hadis, yaitu : pesan yang disampaikan harus dengan perkataan benar, jujur, dan tidak bohong; bisa memberi bekas; berkata yang baik, mulia dan dengan cara lemah lembut serta dengan bahasa yang mudah atau gampang dimengerti oleh komunikan. 


\section{DAFTAR KEPUSTAKAAN}

Aziz, Yusuf dkk, Bahan Ajar Landasan pendidikan, Banda Aceh : UNSYIAH, 2006.

Almath, Muhammad Faiz, 1100 hadis terpilih ; Sinar Ajaran Muhammad, Terj. A. Aziz Salim Basyarahil, Jakarta : Gema Insani Press 1991.

Ardianto Elvinaro, Lukiati Komala, Siti Karlinah, Komunikasi Massa Suatu Pengantar. Bandung : Simbiosa Rekatama Media, 2007.

Bungin H.M Burhan.Sosiologi Komunikasi. Jakarta : Kencana Prenada Media Group, 2006.

Canggara Hafied, Komunikasi Politik: konsep, teori dan Strategi. Jakarta : Rajawali Pers, 2009.

Denis, Mc Quail, Teori Komunikasi Massa. Terj. Ed. 3. Jakarta, Erlangga, 1987.

Departemen Agama RI, Al-Quran dan Terjemahan (Revisi Terbaru). Semarang : CV. Asy Syifa', 1999.

Drajat, Amroeni dkk, Komunikasi Islam dan Tantangan Modernitas. Bandung : Citapusaka Media Perintis, 2008.

Effendy, Onong Uchjana, Ilmu Teori dan Filsafat Komunikasi. Bandung : PT CITRA Aditya Bakti, 2003.

.Dinamika Komunikasi, Cet ke-4 Bandung: PT. Remaja Rosdakarya, 2002.

Spektrum Komunikasi. Bandung : Mandar Maju, 1992.

Harahap, Krina. Kebebasan Pers di Indonesia. Bandung : Grafitri Budi Utami, 2000.

Khoirul, Anam Faris, Fikih Jurnalistik. Jakarta: Pustaka Al-Kautsar, 2009.

Kholil, Syukur, Komunikasi Islami. Bandung: Citapustaka Media, 2007.

Ma'arif, Bambang Saiful, Komunikasi Dakwah Paradigma Untuk Aksi, Bandung : Simbiosa Rekatama Media, 2010.

Marsud, Al-Subandi, Pancasila dan UUD 1945 Dalam Paradigma Reformasi. Jakarta : Rajawali Pers, 2008.

Muhmidayeli, Filsafat Pendidikan, Bandung : Refika Aditama, 2011.

Saefullah, Ujang, Kapita Selekta Komunikasi, Pendekatan Budaya dan Agama.Bandung : Simbiosa Rekatama Media, 2007

Santana, K.Septiawan.Jurnalisme Kontemporer. Jakarta : Yayasan Obor Indonesia :2005

Tankard,dan Severin.Teori Komunikasi, Sejarah, Metode dan Terapan di dalam Media massa. Jakarta : Kencana 2005. 